\title{
Book review: Lithic technological analysis: Theory and practice
}

\author{
Hubert Forestier
}

Muséum National d'Histoire Naturelle, Musée de l'Homme, 17 Place du Trocadéro 75116 Paris, France.

Email: hubforestier@gmail.com

\section{旧石器技术: \\ 理论与实践}

Lithic Technological Analysis: Theory and Practice

Lithic Technological Analysis: Theory and Practice

by Yinghua Li

Social Sciences Academic Press (China), 2017, pp. 459. ISBN 978-7-5201-0787-7

https://www.ssap.com.cn/c/2017-07-12/1057538.shtml

The lithic technological methodology was presented in a systematic way in this book. This method was proposed and established by French prehistorians in the $20^{\text {th }}$ Century and applied to Chinese lithic industries for the first time. The research presented here exhibited the advantage of this methodology in the study of lithic industries and its feasibility in Chinese Palaeolithic research. The lithic technological methodology was based on the concept of "chaîne opératoire" which was proposed in the 1960s by French prehistorian and

Journal of Lithic Studies (2020) vol. 7, nr. 1, 2 p.

DOI: https://doi.org/10.2218/jls.5166

Published by the School of History, Classics and Archaeology, University of Edinburgh ISSN: 2055-0472. URL: http://journals.ed.ac.uk/lithicstudies/

Except where otherwise noted, this work is licensed under a CC BY 4.0 licence. 
anthropologist, A. Leroi-Gourhan. This notion opened a brand-new perspective for prehistoric study and contributed to constructing a multi-levelled explanatory frame. After the 1980s some French prehistorians proposed a series of new concepts such as "schème opératoire", "techno-cognition" and "techno-economy" and formed a set of standardized analytic methods and procedures, so as to facilitate revealing cognitive modes of hominids (e.g. concept, method, technique, procedure, etc.) and interpreting hominids behaviour from a socioeconomic perspective. Since the 1990s a new techno-functional method has been developed, which enabled us to reveal the technique logic involved in tool production and to infer predetermined function and use-pattern of tools. During the last 50 years, this methodology has become a complete system and an independent discipline in prehistory.

From a techno-cognitive perspective the lithic production of hominids involved two basic concepts: one was "débitage", and the other was "façonnage". According to these two concepts of knapping, the author selected 11 sites and conducted detailed analysis so as to reveal different operative schemes used in lithic production. Then Pr. Yinghua Li used "operative schemes" as principal criteria to compare lithic industries from different sites and regions and to reveal the homogeneity and variability of lithic industries of intra and interregions. It was indicated that the débitage of "system C" in terms of additional structure of cores was the most frequently-used "débitage" system, and that the system E and F-bipolar débitage was occasionally present in Chinese Palaeolithic industries. The concept of Levallois (system F), which was largely used in Europe, the Near-East, Middle-Asia, West Asia, Altai and Mongolia, was not actually present in lithic industries older than $50 \mathrm{ka}$ in central-southern and south-west China. In addition, the concept of façonnage represented by bifaces displayed a salient feature. These bifaces were technologically different from the counterpart of classical Acheulean complexes and did not evolve from Early to Late Pleistocene as frequently as Acheulean implements did. It was suggested that the Chinese bifacial phenomenon may reflect different cultural traditions and result from technological convergence which inform the high diversity of hominin migrations.

In summary, despite the presence of some variability in lithic production and several isolated industries in some regions, Chinese Palaeolithic cultures followed an independent, continuous trajectory during most of the Pleistocene.

This book, written in the Chinese language, is a large amount of data that gives us a new perspective on Palaeolithic discoveries made in China during the past decades. This book is a theoretical and practical synthesis that brings out both contributions from Eastern and Western influences to promote the development of lithic studies in China. 